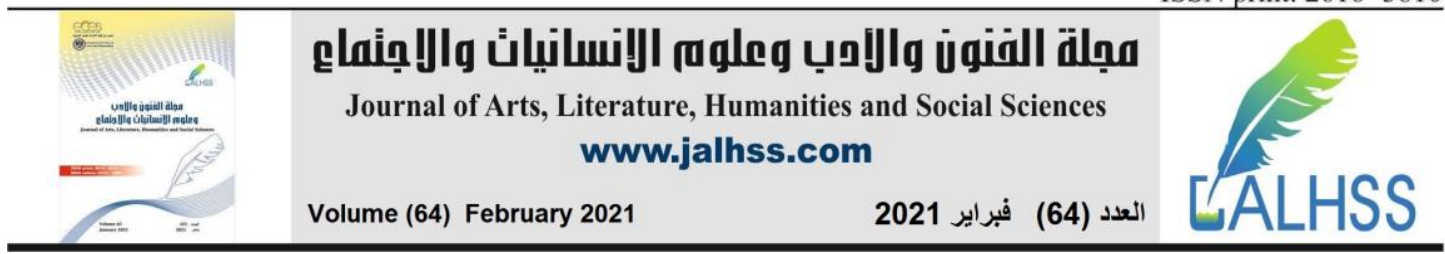

\title{
The Jurisdictional Conflict Between Regional Trade Agreements and The World Trade Organization
}

\author{
Abd Almohsen Alajmy*1 \\ LLM student at Georgetown Law Center - Georgetown Law School \\ Email: Ama467@Georgetown.edu
}

\begin{abstract}
The number of Regional Trade Agreements (RTAs) between countries has significantly increased over the past few decades. RTA may include rights and obligations that are parallel to those of WTO agreement, and provide for its own dispute settlement mechanism that is different from WTO Dispute Settlement Understanding (DSU). This forum clause allows parties to both RTA and WTO to litigate their dispute outside the DSU. This article addresses the issue of jurisdictional conflict between the RTAs and the WTO dispute mechanism over a claim that is violative of both WTO and RTA's obligations.

The main question this article answers is whether it is possible for the forum clause incorporated in RTA to divest the jurisdiction of WTO if invoked during the proceeding. This article analyzes a number of cases and RTAs involving a choice of forum clause before the WTO panel. This paper proceeds to examine different legal principles to find a legal justification to reconcile the jurisdictional scope of both RTA and WTO. As in current international legal principles do not offer an effective solution, this paper suggests that DSU should be amended to provide a set of rules governing the conflict between the RTA and WTO jurisdictions.
\end{abstract}

Keywords: Jurisdictional Conflict, Regional Trade Agreements, World Trade Organization.

\footnotetext{
* LLM Candidate, Georgetown Law School. The author would like to thank Prof.Almas Khan and Prof.Timothy C. Brightbill for their insightful comments and suggestions on the draft of this paper. The author can be reached at: Ama467@Georgetown.edu
} 


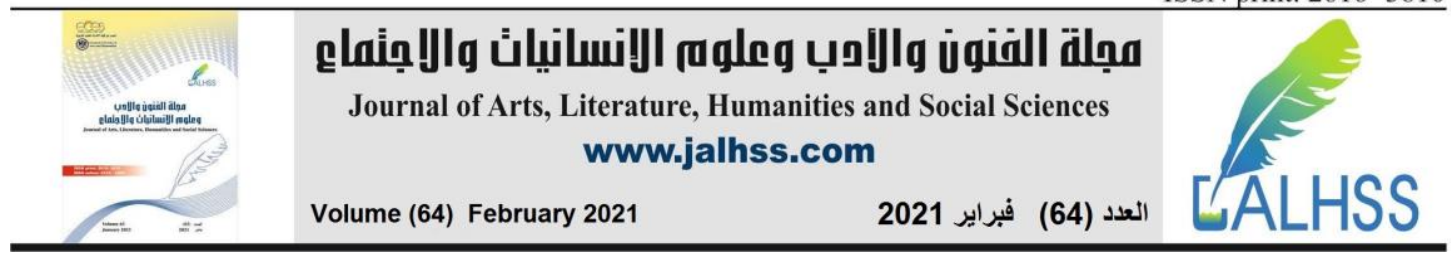

\section{INTRODUCTION}

It is not unique for states to be bound by many treaties that provide for a specific dispute settlement mechanism. General Agreement on Tariffs and Trade (GATT) ${ }^{2}$ allows World Trade Organization (WTO) members to engage in regional trade agreements to enhance the international trade system. WTO covers certain types of trade, like trade of goods, services, and intellectual property. Regional Trade Agreements (RTAs) mostly reframe these aspects of trade. In this case, the rights and obligations of RTAs can be similar to those of the WTO. Parties of RTAs may alternatively go further and agree to incorporate an exclusive dispute settlement clause to their agreement to settle their dispute during the implementation of the treaty. However, Dispute Settlement Understanding (DSU), in Article 23, claims to be the exclusive and compulsory jurisdiction over claims concerning violation of WTO obligations. ${ }^{3}$ The issue of jurisdictional conflict, then, arises when a violation occurs involving a common obligation between RTA and WTO. The question becomes which adjudicative body should settle the matter. The conflict between the WTO jurisdiction and the dispute mechanism of RTAs is foreseeable as the number of RTAs is growing, since many WTO members are also members of multiple RTAs. ${ }^{4}$ Therefore, these states have commitments to perform their obligations under both agreements.

Or, rather, the DSU will provide the governing law to adjudicate claims of violations concerning WTO obligations, then it would also be competent to review RTA's claims if the rights infringed under RTA are identical to those of the WTO. How would the DSU or RTA's dispute settlement body react if the forum selection clause was invoked during the proceeding? Could international and national legal principles offer a solution to resolve this problem?

To avoid WTO jurisdiction over overlapping disputes, some RTA agreements, intentionally, deprive the parties of the right to resort to the DSU either entirely or partially. This raises the issue of the legal effect of these types of clauses, and whether they divest the jurisdiction of WTO. This instance has materialized in many international cases. ${ }^{5}$

The jurisdictional conflict between the WTO and the RTA will result in many negative impacts to the growth of commerce internationally. It is understandable that

\footnotetext{
${ }^{2}$ General Agreement on Tariffs and Trade, October 3o, 1947, 61 Stat. A-i 1, TIAS 1700, 55 U.N.T.S. 194.

${ }^{3}$ DSU Article 23.

${ }^{4}$ WTO, Regional Trade Agreements-Facts and Figures: How Many Regional. Available: https://www.wto.org/english/tratop_e/region_e/region_e.htm\#: :text=back\%20to\%20top,Facts\%20and\%20figures, the \%20GATT\%20or\%20the\%20WTO\%3F.

5 see Candice Whyte, Yuval Shany, The Competing Jurisdictions of International Courts and Tribunals, 12 UNIVERSITY OF MIAMI INT'L AND COMPARATIVE L. REV., 2004.
} 


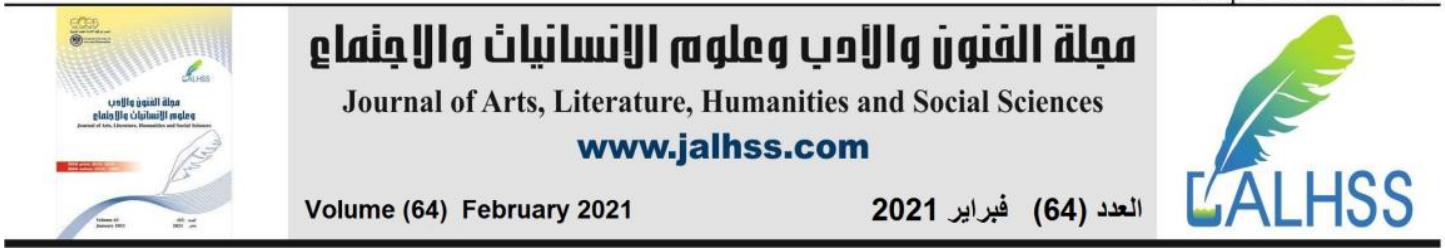

RTA agreements represent the interests of the parties, therefore, the disputing parties have a legitimate right to choose the dispute settlement forum to resolve their disputes. However, if both WTO and RTA tribunals decide the same matter, the parties would encounter difficulties enforcing the rulings in case the outcomes of each award is different.

Part II of this article articulates the current dispute settlement mechanisms under both WTO and Regional Trade Agreements (RTAs) and how they operate. It explains the legal framework of these entities and the scope of their jurisdiction. Part III is an analysis of the issue of jurisdictional conflict between WTO and RTAs. It gives an introduction of the problem and explains the potential conflict based on the current legal text and the language of forum selection clauses used by many RTAs. It then attempts to assess the problem in order to spot the issue. Part IV discusses several cases where the overlap of jurisdiction between WTO and RTA has materialized. Part $\mathrm{V}$ will evaluate many solutions that have been suggested. This part, also, explores different arguments that either strive to rectify the shortcomings of the DSU rules by applying international legal principles, or insist on the validity of the DSU rules to resolve the issue. Part VI presents a recommendation to help overcome the potential obstacle of overlapping jurisdiction.

\section{BACKGROUND}

\section{A. WTO Dispute Settlement Mechanism}

The jurisdiction of WTO dispute settlement is restricted to claims arising under the WTO covered agreements. ${ }^{6}$ Article 23 of DSU states that: "When Members seek the redress of a violation of obligations or other nullification or impairment of benefits under the covered agreements or an impediment to the attainment of any objective of the covered agreements, they shall have recourse to, and abide by, the rules and procedures of this Understanding.",

The dispute mechanism under WTO involves three phases. First, the offending party makes a request for consultation with the other party, and the other party must reply to the request within ten days. Both parties must enter, in good faith, into consultation within thirty days after the other party replies to the request. ${ }^{8}$

The second phase assumes, within 60 days, ${ }^{9}$ the disputing parties did not reach a solution. In that instance, parties proceed to the panel, which is composed of three

6 Pauwelyn. Joost, 'The Role Of Public International Law In The WTO: How Far Can We Go?', 95 J. INT'L L., 535, 554.

${ }^{7}$ Understanding on Rules and Procedures Governing the Settlement of Disputes (DSU), Article 23.

${ }^{8}$ Id, Article 4.3.

${ }^{9} \mathrm{Id}$, Article 4.7 and 4.8. 


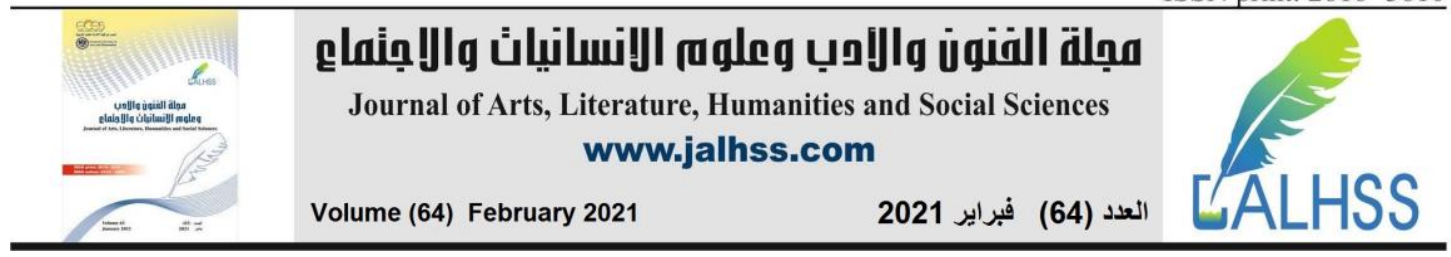

panelists, unless parties agreed otherwise. ${ }^{10}$ Finally, the panel issues the conclusion and its report. The decision of the panel will be adopted by the Dispute Settlement Body (DSU) unless a party to the dispute notifies the DSB of its intention to appeal. ${ }^{11}$ The recommendations and conclusions of the Appellate Body, which generally must be issued within 60 days starting from the notification to appeal by a party, ${ }^{12}$ should be unconditionally adopted by the parties unless the Appellate Body, by consensus, decides not to adopt them. ${ }^{13}$

An RTA dispute cannot be brought before the WTO unless some requirements related to the formation of the RTA are satisfied. RTA should meet many requirements. Some of which are; the "substantially all trade" 14 , or the "substantial sectoral coverage" requirement ${ }^{15}$, whether certain trade policy instruments are considered "other restrictive regulations of commerce"16, and whether the interim agreements contain a schedule of the free trade area in a reasonable time. ${ }^{17}$ Most of these requirements are pre-conditions that an RTA must fulfill in order for RTA's Members to invoke the WTO jurisdiction over disputes arising from the free trade agreement, and to justify their deviation from Most Favored Nation (MFN) obligations. ${ }^{18}$

\section{B. Dispute Settlement Mechanisms in Regional Trade Agreements}

A total of 711 regional free trade agreements have been signed since 1948 until 2020. ${ }^{19}$ Most of RTAs addresses the same issues as WTO agreements do, such as trade in goods and services, intellectual property, customs and valuation provisions, sanitary and phytosanitary provisions (SPS provisions), ... etc.

Almost all of these agreements contain dispute settlement clause to ensure effective implementation of parties' obligations. Dispute settlement mechanism provisions incorporated in the RTAs vary in terms of the language and forum selection clause. Some might be as a choice of forum agreement, which adds another forum in addition to DSU where disputes arising under RTA can be resolved through many fora. For instance, this method is adopted in Article 56 (2) of the EFTA-Singapore FTA. ${ }^{20}$ The

\footnotetext{
${ }^{10}$ Id Article 8.4 and 8.5 .

${ }^{11} I d$, Article 16.4.

${ }^{12} I d$, Article 17.5.

${ }^{13} I d$, Article 17.14.

${ }^{14}$ GATT, Article XXIV.8.b.

${ }^{15}$ GATS, Article V.

${ }^{16}$ GATT, Article XXIV.8.a.i.

${ }^{17}$ GATT, Article XXIV 5 (c).

${ }^{18}$ Henry Gao and C. L. Lim, Saving The WTO From The Risk of Irrelevance: The WTO Dispute Settlement Mechanism As A 'Common Good' For RTA Disputes, J. InT'L ECON. L., 904.

${ }^{19}$ WTO, Regional Trade Agreements-Facts and Figures: How Many Regional, supra (n 3).

${ }^{20}$ EFTA-Singapore Free Trade Agreement, 26 June 2002.
} 


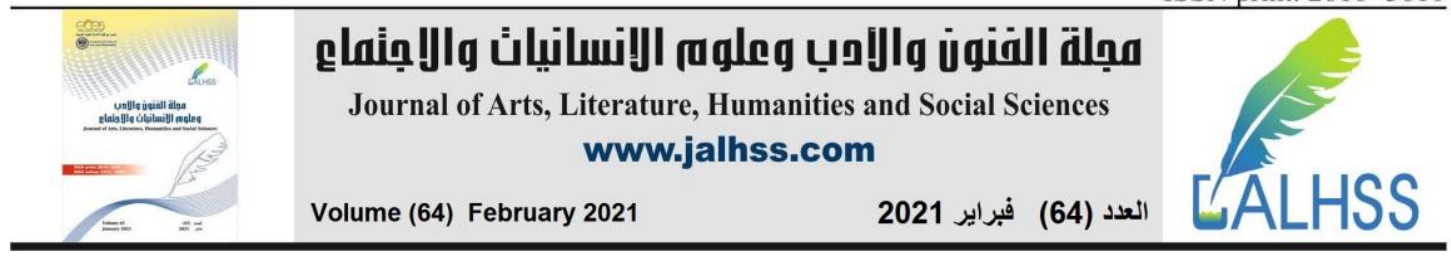

majority of the RTAs notified to GATT can be classified under this category as they contain a provision permitting the complaining party to bring its claim either under the dispute settlement mechanism specified in the RTA agreement or under the WTO's dispute settlement. ${ }^{21}$ For example, NAFTA Article 2005 (1) states: "Subject to paragraphs 2, 3 and 4, disputes regarding any matter arising under both this Agreement and the General Agreement on Tariffs and Trade, any agreement negotiated thereunder, or any successor agreement (GATT), may be settled in either forum at the discretion of the complaining Party." 22

The second category is the exclusive jurisdiction clause, under which only one tribunal or panel will be competent to adjudicate the matter resulting from RTA agreement. Thus, parties must bring their claims under the specified dispute settlement mechanism agreed on. For instance, NAFTA restricts the parties to litigate their disputes under NAFTA dispute settlement mechanism when the claim involves measures taken to protect human, animal, plant life, or health, or environment protection and the defendant requests the claim be adjudicated under NAFTA. ${ }^{23}$

Last, the preferred forum, which states that any dispute should be brought within the RTA's dispute settlement procedure as an exclusive method if the dispute is first submitted under that procedure. Similarly, if the dispute is filed before the WTO settlement, that would prevent the dispute from being brought under RTA. An example of that would be Article 2005.6 of the North American Free Trade Agreement Protocol (NAFTA), ${ }^{24}$ which provides that:

"Once dispute settlement procedures have been initiated under Article 2007 or dispute settlement proceedings have been initiated under the GATT, the forum selected shall be used to the exclusion of the other, unless a Party makes a request pursuant to paragraph 3 or 4 .

In this type, the parties agree on more than one forum in advance. However, it can be changed if the parties collectively agree so. ${ }^{25}$

\footnotetext{
${ }^{21} I d, 196$.

${ }^{22}$ NAFTA, 2005 (1).

${ }^{23}$ North American Free Trade Agreement Among the Government of the United States of America, the Government of Canada, and the Government of the United Mexican States (NAFTA), 1 January 1994, Chapter Twenty: Institutional Arrangements and Dispute Settlement Procedures Article. 2005(4)(a).

${ }^{24}$ NAFTA, Article 2005.6.

${ }^{25}$ Hillman, Jennifer, conflicts Between Dispute Settlement Mechanisms in Regional Trade Agreements and the WTO What Should the WTO Do? CORNELL INT'L L.J. 193 (2009), 195.
} 


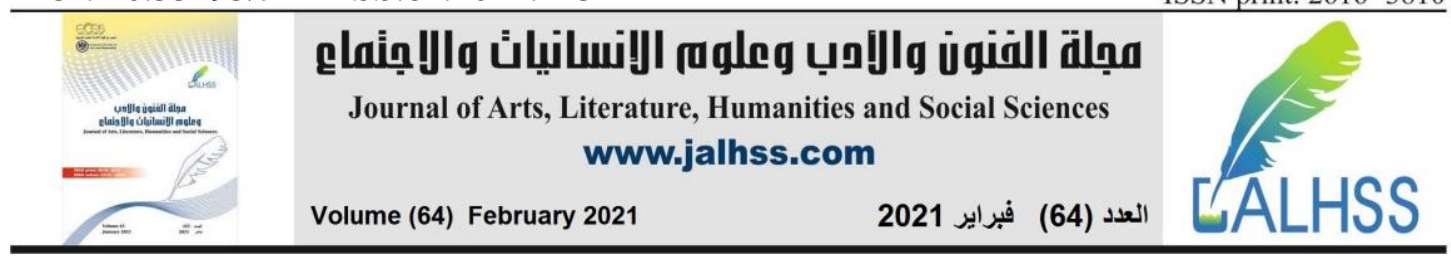

III. ISSUE

\section{A. Overview}

The jurisdictional conflict stems from the clashes between the forum clauses incorporated in relevant international treaties that provide for additional jurisdictions. This conflict occurs in the situation where one claim can be brought to different dispute settlement systems for various reasons. Under some circumstances, the possibility of having two distinct competent jurisdictions to decide the claim may lead to difficulties if they are invoked in parallel or in sequence. In particular, these two, or more, adjudicative bodies may claim final jurisdiction which prevents the parties from seeking redress through another tribunal. It is, also, possible that these jurisdictions will reach a different conclusion which can lead to different outcomes. ${ }^{26}$

Despite the fact that settlement provisions in many RTAs may be compatible with the WTO rules, the forum clauses in these agreements may give rise to a conflict with respect to the applicable law over the matter as well. Particularly, the overlap can be expected when the RTA has substantive obligations that are parallel to WTO's obligations and the forum clause in RTA obliges or gives the opportunity to the parties to recourse to RTA's dispute settlement mechanism agreed on, exclusively or in addition to DSU. The immediate question here is that is it possible for the DSU to seize its jurisdiction in favor of RTA dispute settlement if the forum clause is invoked during the proceeding? DSU mandates the Panel to "address the relevant provisions in any covered agreement or agreements cited by the parties to the dispute" and conduct "an objective assessment of . . the applicability of and conformity with the relevant covered agreements." 27 It seems that the Panel could be in breach of its obligations under the DSU if it fails to address the consistency of the forum selection clause of RTA if it is invoked and cited by the defendant, with the requirements of GATT Article XXIV.

Moreover, the Marrakesh Treaty establishing the $\mathrm{WTO}^{28}$ states that multilateral Trade Agreements are "binding on all Members"29 and "each Member shall ensure the conformity of its laws, regulations and administrative procedures with its obligations as provided in the annexed Agreements." 30 Therefore, if the parties of RTA containing forum clause are also parties of the WTO, they should be committed to the RTA agreement signed.

\footnotetext{
${ }^{26}$ Kyung Kwak and Gabrielle Marcea, Overlaps and conflicts of Jurisdiction between the World Trade Organization and Regional Trade Agreements, 41 THE CANADIANYEARBOOK OF INT'L L., 84, 86.

${ }^{27}$ DSU Article 11.

${ }^{28}$ Marrakesh Agreement Establishing the World Trade Organization, Apr. 15, 1994, 1867.

${ }^{29}$ Id, Article III (2).

${ }^{30} I d$, (4).
} 


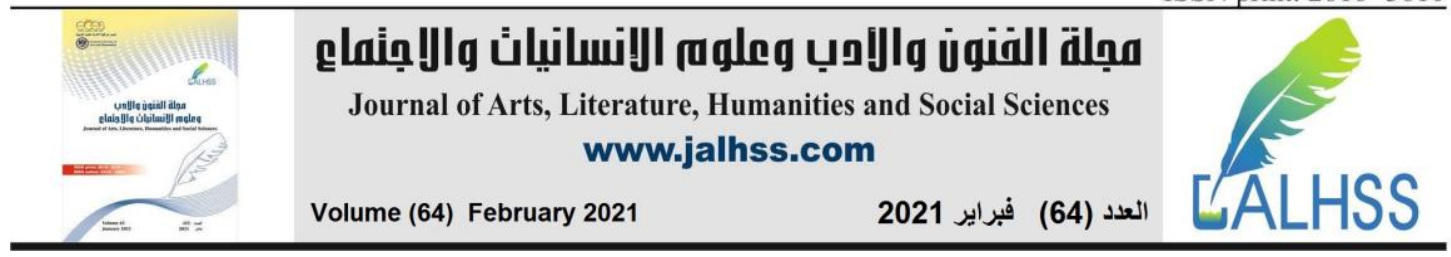

\section{B. DSUv. RTA}

A number of scholars hold the view that DSU will have the exclusive jurisdiction over WTO violations claims relying on Article 23, which states that: "When Members seek the redress of a violation of obligations or other nullification or impairment of benefits under the covered agreements or an impediment to the attainment of any objective of the covered agreements, they shall have recourse to, and abide by, the rules and procedures of this Understanding.",31

They claim that Article 23 cannot be read in a vacuum, and the meaning of this article is that the DSU has "not only compulsory jurisdiction over matters arising under the covered agreements, but that it also has exclusive jurisdiction over such matters." 32 By interpreting that Article, they insist that it imposes on the WTO member seeking redress for violations under covered agreements an obligation to use DSU procedures. Therefore, once the complaining party submits a request for a panel, the panel is automatically established. ${ }^{33}$ This opinion moves on to confirm that final decision of that panel or the Appellate Body is binding on all parties. ${ }^{34}$

From a different angle, some scholars tend to believe that it is possible for a DSU panel to apply the RTA rules. Article 7 of the DSU articulates the relevant rules to be applied by the WTO's panel, and the mission of the panel, which is "to examine, in the light of the relevant provisions in (name of the covered agreement(s) cited by the parties to the dispute), the matter referred to the DSB by (name of party) in document ... and to make such findings will assist the DSB in making the recommendations or in giving the rulings provided for in that/those agreement(s)." 35 Also, the panel has an obligation to further "address the relevant provisions in any covered agreement or agreements cited by the parties to the dispute." RTA rules should be applied through Article 7 of the DSU when these rules are cited by either party to the dispute during the proceeding before the WTO's panel.

\section{Assessment}

The reliance on the language of Article 23 raises the question of the possibility of RTA to prevail if it has similar provisions as the WTO and requires the parties to bring any dispute arising under this agreement to RTA's dispute settlement. Would that language deprive parties of their right to access the WTO dispute settlement mechanism, ${ }^{37}$ since the RTA imposes the same obligations?

\footnotetext{
${ }^{31}$ Steger, Debra P., Jurisdiction of the WTO (2004). Proceedings of the 98th Annual Meeting of the American Society of International Law, 142-147, 2004, 3-4.

${ }^{32} I d$.

${ }^{33} \mathrm{Id}$.

${ }^{34} \mathrm{Id}$.

${ }^{35}$ DSU, Article 7.1.

${ }^{36}$ DSU, Article 7.2.

${ }^{37}$ Hillman, Jennifer, supra (n 13), 197.
} 


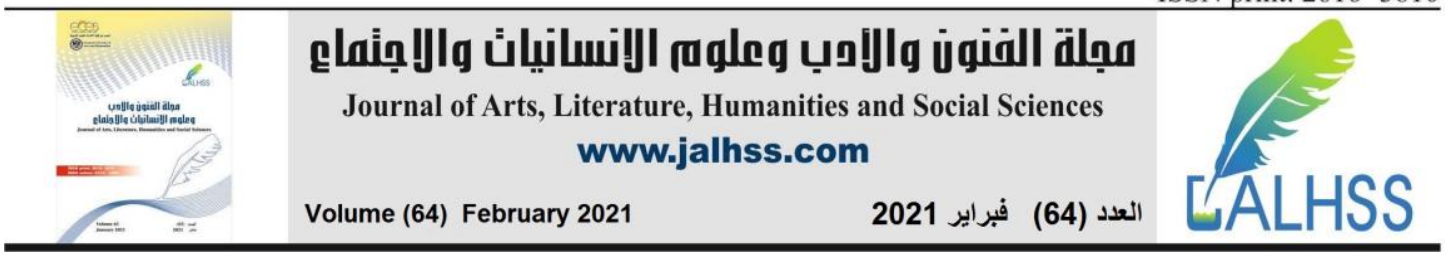

The boundary between RTA and the DSU dispute settlement is vague. Even though GATT recognizes the validity of RTA as part of GATT and the WTO legal system, the distinction between these dispute settlement mechanisms needs to be drawn as this ambiguity might hamper the effectiveness of the WTO dispute mechanism.

The overlap between the substantive obligations and multiple dispute fora requires a clarification on the relationship between these international agreements as long as the WTO members are allowed to initiate WTO proceedings seeking redress of a violation of RTA agreement obligations. ${ }^{38}$ There are a number of cases that have triggered the problem.

The exclusivity of the WTO in respect of violation of WTO obligations may be called into question when the RTA provides for a forum selection clause in addition to the WTO. In this situation, we should distinguish between two examples. First, if the forum selection clause elects RTA as an alternative dispute mechanism, in this situation, the WTO can adjudicate the matter as the RTA does not deny the WTO's competency. Note that, allowing WTO to hear the claim, in the presence of alternative forum clause, does not preclude RTA's jurisdiction. The question then becomes what if the rulings of these two different mechanisms are contradictory? In fact, there is an example of these conflicting rulings between the WTO and the RTA. Canada brought actions against U.S. over softwood lumber countervailing and anti-dumping measures, initiating three NAFTA proceedings in addition to four claims in the DSU. The WTO panel ruled in favor of U.S. ${ }^{39}$ while NAFTA panel rejected U.S. claim on the ground that the injury determination was not supported by sufficient evidence. Now, each party has a ruling from a binding and competent panel. ${ }^{40}$

Indeed, this is not the only problem that occurs; DSU has been precluded in many RTA agreements, as we will see. Some RTAs stipulate that parties cannot invoke their right of the WTO dispute settlement. When issue comes up in the course of performing their obligations, the complaining party should only submit their claim to the forum listed in the RTA agreement. The question here is what if the party initiates a DSU proceeding? Will this provision divest DSU's jurisdiction?

\section{Paradigms of Jurisdictional Conflict between the WTO and the RTA}

\section{A. Treaties Providing for Another Forum in Addition To The WTO}

In this method, some RTAs' approach provides a lenient interaction with parties' obligations under another international agreement in terms of a competent forum. As an example, EU-Japan Economic Partnership Agreement (EPA) was signed between

\footnotetext{
${ }^{38} \mathrm{Id}$.

${ }^{39}$ The appellate body overturned DSU decision; however, that does not negate the fact there is a potential jurisdictional conflict. See Appellate Body Report, United States-Final Dumping Determination on Softwood Lumber from Canada, at Art 21.5, 11 144-147, WT/ DS264/AB/RW (Aug. 15, 2006).

40 Jennifer Lan, U.S. and Canadian Trade War over Softwood Lumber: The Continuing Dispute, 13 LAW \& BUS. REV., 209, 214-16.
} 


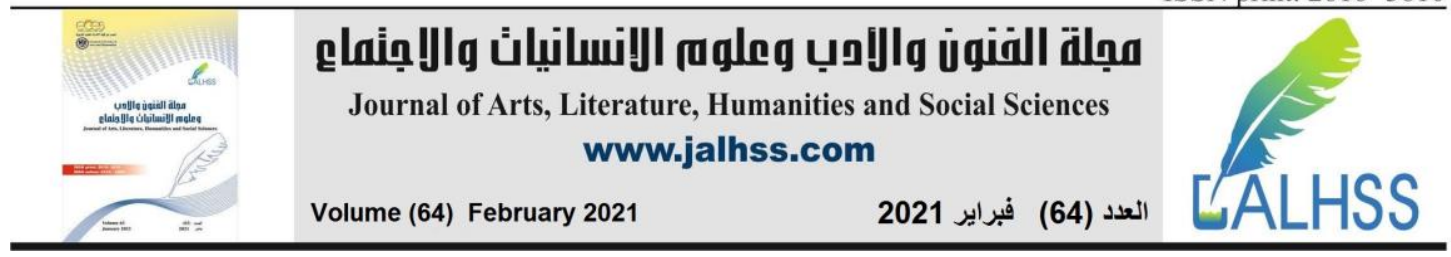

EU and Japan on February 1, 2019. Article 2.15 of this agreement allows parties to adopt restrictions on exportation or sale for export of any good listed in annex 2-B in accordance with GATT Article XI.2 (exceptions to quantitative restrictions). However, parties should "seek to limit that prohibition or restriction to the extent necessary, giving due consideration to its possible negative effects on the other Party." $" 41$ This provision expands the party's ability to impose restrictions as long as these measures are necessary. There is nothing in the treaty defining the term necessary in relation to these restrictions, which means parties have the discretion to assess necessity. In contrast, GATT Article XI.2 opines that the necessary circumstances, where party may impose restriction on exportation, must be narrowly tailored to certain situations ${ }^{42}$

Article 21.7 of EPA agreement provides ${ }^{43}$ : "Where a dispute arises with regard to the alleged inconsistency of a particular measure with an obligation under this Agreement and a substantially equivalent obligation under any other international agreement to which both Parties are party, including the WTO Agreement, the complaining Party may select the forum in which to settle the dispute."

Assuming Japan, as it is party to both EPA agreement and WTO, arbitrarily imposes restrictions on exportation to EU and these measures are inconsistent with Article XI.2 of GATT. Japan can justify these measures as necessary; it cannot be held liable since there is no definition on what can be necessary under Article 2.15 (2) (b) of EPA. Assume further that the EU resorted to dispute settlement under that agreement and the claim was denied. EU is still able to bring the same matter to WTO despite the forum clause incorporated in EPA agreement as there is an obligation imposed on the WTO Dispute Settlement Body (DSB) that its ruling "cannot add to or diminish the rights and obligations provided in the covered agreements." ${ }^{44}$ This provision prohibits DSB from declining to exercise jurisdiction as long as the matter falls under WTO obligations.

The panel will encounter difficult questions. One is whether the ruling issued by EPA tribunal is binding; second is whether DSU has jurisdiction, if the clause is invoked by Japan; third is whether the assessment will be based on EPA treaty or GATT; and finally, if the DSU ruled in favor of EU there will be two different rulings.

Another example is the United States, Mexico and Canada Free Trade Agreement (CUSMA), which was effective on July 1, 2020. That agreement contains a dispute settlement section, chapter 30 . Article 31.3 of that chapter provides ${ }^{45}$ :

1. If a dispute regarding a matter arises under this Agreement and under another international trade agreement to which the disputing Parties are party, including the WTO Agreement, the complaining Party may select the forum in which to settle the dispute.

\footnotetext{
${ }^{41}$ EU-Japan Economic Partnership Agreement (EPA), Article 2.15 (2) (b).

${ }^{42}$ Article XI. 2.

${ }^{43}$ ERA, Article 21.7.

${ }^{44}$ DSU, Article 3.2.

${ }^{45}$ CUSMA, Article 31.3.
} 


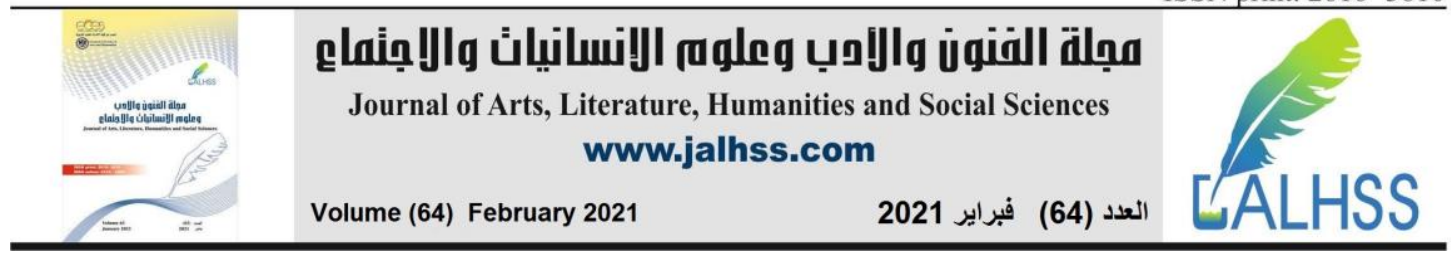

2. Once a complaining Party has requested the establishment of, or referred a matter to, a panel under this Chapter or a panel or tribunal under an agreement referred to in paragraph 1, the forum selected shall be used to the exclusion of other fora.

Based on this language, the party has the right to recourse to either forum only when a dispute arises under USMCA agreement and another international agreement. Once the proceeding is initiated, the tribunal will be exclusively competent.

In the same vein, in 2002 party States of MERCOSUR, ${ }^{46}$ the Republic of Argentina, the Federative Republic of Brazil, the Republic of Paraguay and the Eastern Republic of Uruguay, agreed to sign the Olivos Protocol. This protocol provides for a permanent dispute settlement mechanism, which aims to establish a unifying jurisprudence on matters derived from the MERCOSUR.

Article 1.2 of 2002 Olivos Protocol, which is the most recent dispute settlement mechanism set up within MERCOSUR, contains a choice of forum clause regarding disputes that fall within both the WTO and MERCOSUR's jurisdiction:

"Disputes falling within the scope of application of this Protocol that may also be referred to the dispute settlement system of the World Trade Organisation or other preferential trade systems that the Mercosur State Parties may have entered into, may be referred to one forum or the other, as decided by the requesting party. Provided, however, that the parties to the dispute may jointly agree on a forum." 47

However, once the complaint has been submitted to one tribunal, that will prevent the parties to resort to any other tribunal as Article 1.2 provides:

"Once a dispute settlement procedure pursuant to the preceding paragraph has begun, none of the parties may request the use of the mechanisms established in the other fora . .."48

The question here is what would the WTO do if one party, in violation of USMCA or MERCOSUR obligations that are similar to those of the WTO, resorts to DSU after submitting its claim to the RTA tribunal? Would the WTO respect the exclusion provision and decline to decide the case?

This situation has previously materialized before the WTO panel on Argentina Definitive Anti-Dumping Duties on Poultry from Brazil. Brazil complained and lost its claim to MERCOSUR. Then, it decided to resort to the WTO dispute settlement. The panel, notably, found that old Brasilia Protocol was still applicable and had no

\footnotetext{
${ }^{46}$ MERCOSUR is a union of States obtain legal personality under International Law [check clause wordingl, whose origin is the Asunci6n Treaty of March 26, 1991. The treaty was executed by the Republic of Argentina, the Federative Republic of Brazil, the Republic of Paraguay and the Eastern Republic of Uruguay.

${ }^{47}$ Olivos Protocol, Article 1.2.

${ }^{48} \mathrm{Id}$
} 


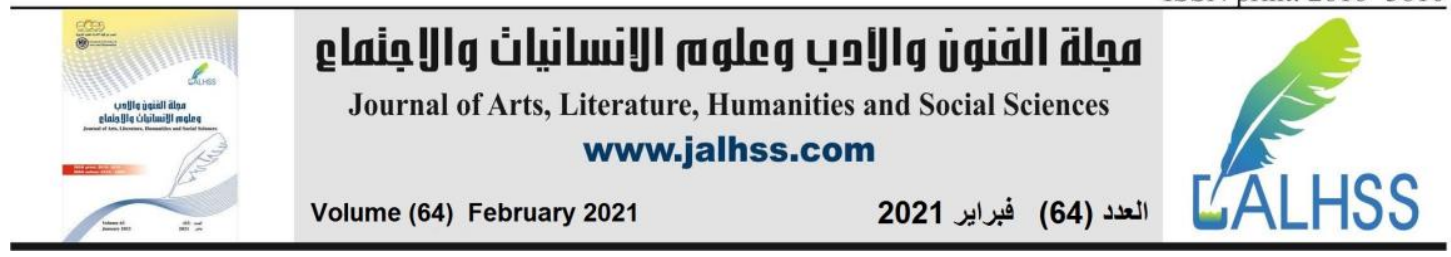

prohibition with respect to bringing subsequent cases before the WTO. The panel, in its reasoning, stated that ${ }^{49}$ :

"We note that Brazil signed the Protocol of Olivos in February 2002. Article 1 of the Protocol of Olivos provides that once a party decides to bring a case under either the MERCOSUR or WTO dispute settlement forums, that party may not bring a subsequent case regarding the same subjectmatter in the other forum. The Protocol of Olivos, however, does not change our assessment, since that Protocol has not yet entered into force, and in any event it does not apply in respect of disputes already decided in accordance with the MERCOSUR Protocol of Brasilia. Indeed, the fact that parties to MERCOSUR saw the need to introduce the Protocol of Olivos suggests to us that they recognised that (in the absence of such Protocol) a MERCOSUR dispute settlement proceeding could be followed by a WTO dispute settlement proceeding in respect of the same measure."

It can be concluded from the panel explanation that the exclusion clause actually had a legal effect before the panel and if the Protocol was effective the panel would have been willing to enforce it, otherwise the panel would not have addressed this defense. $^{50}$

\section{B. Treaties Precluding WTO Jurisdiction}

In this paradigm the situation is more complicated. The RTA sometimes includes an explicit provision to preclud the DSU from hearing future disputes. India, for example, signed a bilateral agreement with EC on November 12, 1997 to reach a solution and not to invoke the WTO dispute settlement. The agreement was notified to DSB in accordance with Article 3.6 of DSB, containing the following provision:

“... the European Communities will refrain from action under GATT Article XXII or Article XXIII as regards those restrictions [maintained by India on import of industrial, agricultural and textile products] during the phasing-out period as defined below, as long as India complies with its obligations under this exchange of letters.",51

After the agreement, EC brought action before DSU related to India-Auto. India argued that the DSU lacked jurisdiction over the dispute as the parties had agreed not to invoke the WTO dispute settlement, also contending that the bilateral agreement took away EC right to resort to DSB. ${ }^{52}$ The panel did not address the question whether the bilateral agreement divests the jurisdiction from the WTO dispute settlement and

49 Panel Report, Argentina-Definitive Anti-Dumping Duties on Poultry from Brazil, WT/DS241/R, adopted on 19 May 2003 (not appealed), 7.38.

${ }^{50}$ Pauwelyn, supra (n 36), 1013.

${ }^{51}$ India-Quantitative Restrictions on Imports of Agricultural, Textiles and Industrial Products, Notification of Mutually Agreed Solution, letter signed by the Ambassador and Permanent Representative of the European Commission to the WTO. available at: file:///Users/user/Downloads/234.pdf

52 Panel Report, India-Measures Affecting the Automotive Sector ("IndiaĐAutos"), WT/DS146/R and Corr.1, WT/DS175/R and Corr.1, adopted 5 April 2002, at para. 4.30. 


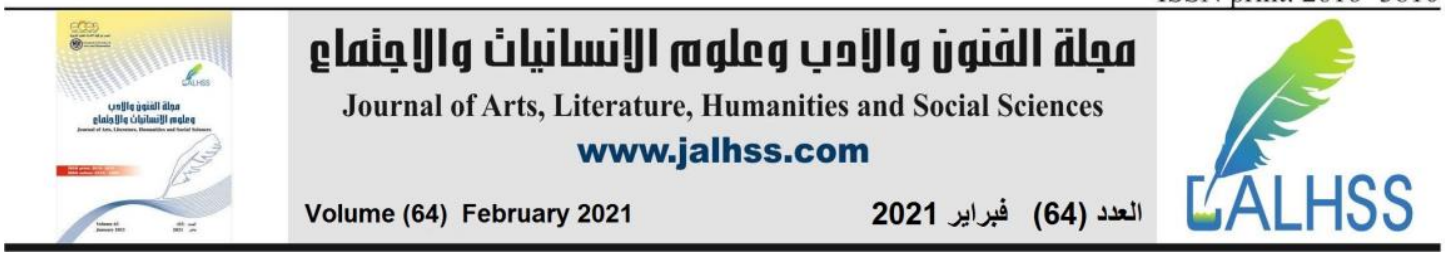

whether the forum selection clause was binding by finding that the matter was not covered by the settlement provision. ${ }^{53}$

This paradigm might come in different wording. For instance, Article 19.5 of the Closer Economic Partnership Arrangement (CEPA), which was signed by Mainland China and Hong Kong, stipulates that "any problems arising from the interpretation or implementation of the CEPA" shall be settled "through consultation in the spirit of friendship and cooperation."

It has been argued that if the dispute results under an agreement containing a clause that denies the jurisdiction of the WTO over the dispute, that means the DSU's panel has an obligation to decline to decide the matter by virtue of the agreement. ${ }^{54}$ However, this opinion contradicts with Article 23 of DSU, which, as a general principle, subjects all WTO matters to be resolved under DSU.

\section{Treaties Providing for An Exclusive Jurisdiction}

NAFTA, in chapter 20, adopted the exclusive forum regime. If the dispute relates to environmental or health protection, the adverse party can insist that the dispute be adjudicated under NAFTA. In international context, the idea of exclusive jurisdiction also poses a risk to other tribunals' jurisdiction. Article 292 of EC treaty, for instance, states that:

"Member States undertake not to submit a dispute concerning the interpretation or application of this Treaty to any method of settlement other than those provided for therein." 55

Does this text prevent EU members to recourse to any EU international tribunal other than European Court of Justice? Based on the plain language of the text, the answer seems to be no, EU members can actually resort to any other international tribunals unless the dispute concerns interpretation of EC treaty. The difficult question is what happens when one party during the proceeding raises an issue involving EC and WTO obligations?

This conflict between EC and another international tribunal, in fact, occurred recently in Ireland v. United Kingdom. In that case, Ireland filed claims regarding violations under the United Nations Convention for the Law of the Sea (UNCLOS). Ireland accused MOX (mixed oxide fuel) plant_of discharging radioactive waste into the Irish sea. This plant was managed by the United Kingdom. The International Tribunal for the Law of the Sea found that there was prima facie jurisdiction according to Article

\footnotetext{
${ }^{53} I d$.

${ }^{54}$ Pauwelyn, Joost, How to Win a WTO Dispute Based on Non-Wto Law? Questions of Jurisdiction and Merits. Journal of World Trade, 37, 998, 1008.

${ }^{55}$ European Commission, signed in 1951, Article 292.
} 


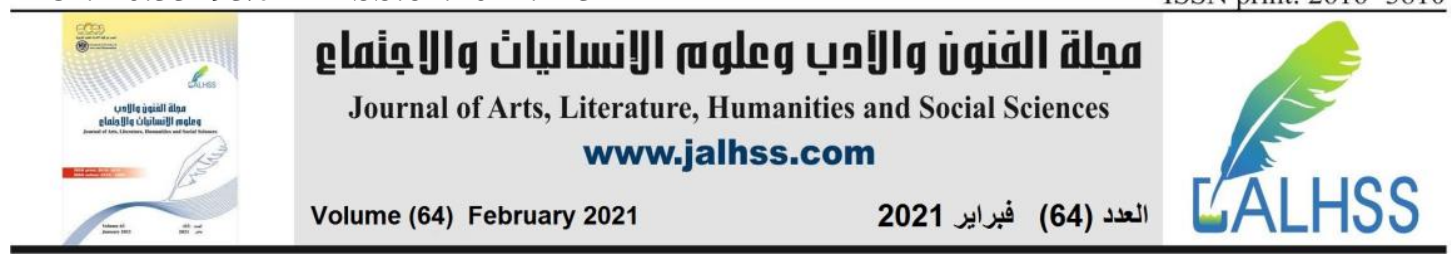

288.1 of UNCLOS, which states: "A court or tribunal referred to in article 287 shall have jurisdiction over any dispute concerning the interpretation or application of this Convention which is submitted to it in accordance with this Part." ${ }^{.56}$ The tribunal constituted to decide the case. Contrastingly, the panel decided to suspend the proceeding in response to UK arguments that the dispute fell, exclusively, within the scope of EC jurisdiction in pursuance of Article 292 of EC treaty. The arbitral panel refused to answer the question as to whether the dispute fell, partially, under the EC's exclusive jurisdiction and decided that the question is "to be decided within the institutions of the European Communities, and particularly by the European Court of Justice." ${ }^{, 57}$ Therefore, the tribunal refrained from continuing the proceeding upon the existence of the exclusive jurisdiction provision. The immediate question is that what would be the decision of the WTO's panel if a case submitted to it involved overlapping substantive obligations between the WTO and EC?

Some scholars tend to the UNCLOS's rules and call for it to be applied even by the DSB. In justifying that, they list number of reasons: first, according to Article 133 of the EC Treaty, which states that the EC's common commercial policy falls within the exclusive competence of the EC, EU members have no legal capacity to exercise their right to resort to the WTO dispute settlement, because they relinquished that right. ${ }^{58}$ At least not when the matter involves multiple issues concerning both the WTO and EC obligations. Furthermore, the dispute between EU members and non-EU members should also be adjudicated by EC. Therefore, the lack of competence resulting from EC treaty applies beyond EU.

There are two observations in this opinion. First, it weighs the side of the EC, and not the WTO, without reasonable justification. Why should the WTO rules not apply since the language of Article 23 DSU has the same legal strength? We can assume EU members relinquished their right to bring their claims under EC in favor of the WTO as this opinion alludes to the autonomy of the states.

\section{SOLUTIONS SUGGESTED TO RESOLVE THE JURISDICTIONAL CONFLICT}

\section{A. Res Judicata}

Bin Cheng states that "recognition of an award as res judicata means nothing else more than recognition of the fact that the terms of that award are definitive and obligatory." ${ }^{59}$ In the same vein, Barnett has described res judicata as:

[a] .. judicial decision of special character because, being pronounced by a court or tribunal having jurisdiction over the subject-matter and the parties, it disposes finally and conclusively of the matters in controversy, such that - other than on appeal - that subject-matter cannot be relitigated between the

\footnotetext{
${ }^{56}$ Order of 3 December 2001, at www.itlos.org, Case No. 10.

${ }^{57}$ Order No. 3 of 24 June 2003, at http://www.pca-cpa.org/PDF/MOX\%20Order\%20no3.pdf, 8.

${ }^{58}$ Pauwelyn, supra (n 36), 1010.

${ }^{59}$ Bin Cheng, General Principles of Law as Applied by International Courts and Tribunals, 1987, 336-7.
} 


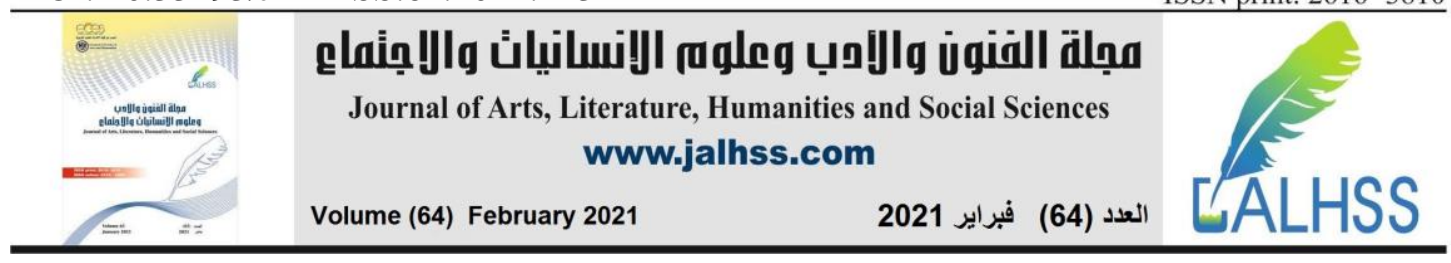

same parties or their privities. Instead, the subject-matter becomes - as the Latin reveals - 'a thing adjudicated', with res judicata thereafter standing as the final and conclusive resolution of the parties' dispute." 60

The concept of res judicata has been recognized by international courts and tribunals such as International Court of Justice (ICJ), the European Court of Justice (ECJ), and arbitral tribunals, as a legally binding principle. ${ }^{61}$

The applicability of res judicata is one of the most controversial issues in the WTO law. The principle of res judicata is a non-WTO norm and not included in any WTO covered agreement in DSU. ${ }^{62}$ DSU tribunal relies on Articles 1.1, 3.2, 7, 11, and 19.2 to decide any case. ${ }^{63}$ To determine whether a WTO member has violated the rights of another member, DSU would use the agreement signed by these members as substantive law to determine the rights and obligations of each party.

Even though the DSU is bound by the articles set forth above as applicable law, once the jurisdiction of DSU is properly established "it is less clear what laws panels and the Appellate Body may apply." ${ }^{\circ 4}$ Scholars claim that award rendered by RTA's dispute settlement mechanism has res judicata effect, therefore, DSU should decline to exercise jurisdiction. ${ }^{65}$ The motive behind this view may be based on the characterization of the RTA rules as general international law. However, most laws of international agreements, such as those related to the environment and human rights, have not been applied by DSU tribunal. Rather, they are taken into consideration to determine rights and obligations of the WTO covered - agreement. ${ }^{66}$

The basis of applying res judicata to the DSU is debatable. It has been suggested that this doctrine be applied through the inherent power of the WTO tribunal. Inherent power can be defined as "powers that the judge enjoys by the mere fact of his or her status as a judge. They are functional powers, only to be exercised when necessary for the purpose of fulfilling the judicial function. ${ }^{.67}$

It is undisputed that because the WTO tribunal acts in many regards as a court, it can be classified as judicial body. Hence, it should recognize the concept of inherent power since this concept is adopted by all international judicial bodies and there is no prohibition for the WTO to do so. ${ }^{68}$ Particularly, as there is no treaty or explicit language that specifies whether the non-WTO rules or norms of international law can

\footnotetext{
${ }^{60}$ Peter R. Barnett, Res Judicata, Estoppel and Foreign Judgments, 2001, 92-8.

${ }^{61} I d, 143$.
}

${ }^{63}$ DSU, Articles 1.1, 3.2, 7, 11, 19.2 are substantially procedural and instruct the panel to apply the rules of covered agreement underlying the dispute as substantive law.

\footnotetext{
${ }^{64}$ Isabelle Van Damme, Treaty Interpretation by the WTO Appellate Body, 21 EUR. INT'L. L., 13.

${ }^{65}$ Hillman, Jennifer, supra (n 13), 203.

${ }^{66}$ Nguyen Tan Son, Towards a Compatible Interaction between Dispute Settlement under the WTO and Regional Trade Agreements, 5 MACQUARIE J. Bus. L. 113 (2008), 130.

${ }^{67}$ Isabelle Van Damme, supra (n 63).

${ }^{68}$ Nguyen Tan Son, supra (n 47), 131.
} 


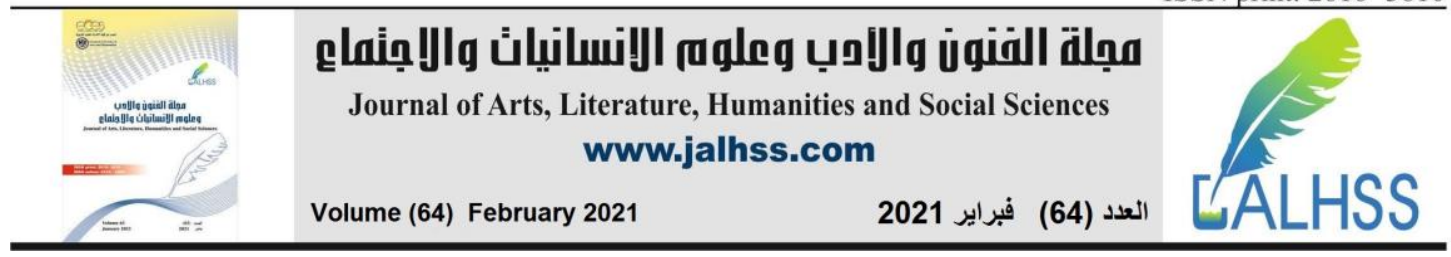

be extended to the WTO disputes, inherent power can be the only basis for res judicata. $^{69}$

In my view, the applicability of res judicata in the WTO's disputes, based on inherent power doctrine, might face an obstacle of the lack of state consent. Simply put, the WTO members should agree explicitly to the application of res judicata in the WTO's disputes. Such consensus is nonetheless unlikely to happen as this might be inconsistent with the WTO's obligations to designate the DSU as dispute settlement mechanism to adjudicate WTO's disputes. Otherwise, that means the WTO encourages its members to settle their disputes in an outside forum. This would be incompatible with the fundamental principle of Article 23 of DSU. The only way to accept res judicata is for the concept to be recognized explicitly in the DSU.

However, adopting res judicata by the panel does not settle the problem. Assuming res judicata can be applied by DSU somehow to avoid subsequent proceeding on the same matter before the WTO's panel, it does not offer a decisive solution for the concurrent proceedings before both DSU and RTA panels.

\section{B. RTA Rules Are the Substantive Applicable Law}

There is no doubt that WTO panels have jurisdiction over disputes arising from the WTO's obligations. Under Article 1.1 of the DSU, the Article 23 only applies to "disputes brought pursuant to the consultation and dispute settlement provisions of the agreements listed in Appendix 1 to this Understanding referred to in this Understanding as the "covered agreements." "70 The question is whether this Article gives the parties the ability to use the RTA's obligation as a defense before the WTO's panel if it is similar to that of the WTO. To put it differently, Article XX of GATT prohibits any "arbitrary or unjustifiable discrimination" between parties. ${ }^{71}$ According to these three Articles, as they are integrated, can a party to RTA justify that the violation is justifiable discrimination?

In fact, the problem here is related to the applicable law, which differs from jurisdiction. Article 7.1 and 7.2 of DSU establish an obligation of the panel, "in the light of the relevant provisions,"72 to "address the relevant provisions in any covered agreement or agreements cited by the parties to the dispute." the applicable law in DSU encompasses the rules of the regional trade agreement if they are cited by the disputing parties, and the RTA agreement contains the WTO obligations. Therefore, for the applicable law to be claimed before the WTO, involving RTA, includes the non-WTO rules.

\footnotetext{
${ }^{69} I d$.

${ }^{70}$ DSU, Article 1.1

${ }^{71}$ GATT, Article XX.

${ }^{72}$ DSU 7.1.

${ }^{73}$ DSU 7.2.
} 


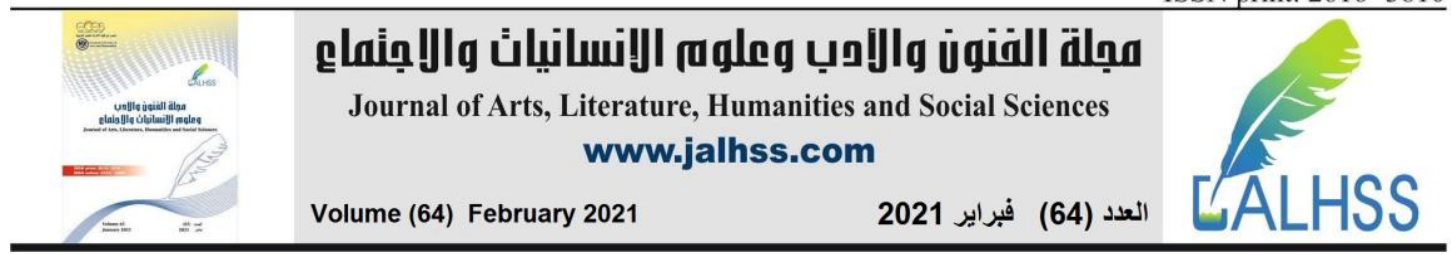

Some scholars have emphasized that these provisions in the DSU should be read to allow the WTO's panel to apply non-WTO law to the dispute even if that precludes the WTO's rules and their reasons are:

First, the WTO panels have not limited themselves to the four corners of the WTO covered agreement. They have referred, multiple times, to the general public international law principles, namely customary international law. ${ }^{74}$

Second, DSU, in Article 3.2, clearly states that WTO covered agreements must be clarified "in accordance with customary rules of interpretation of public international law." 75 Based on that, the Vienna Convention on The Law of Treaties stipulates in Article 31(3) that a treaty must be interpreted in light of "any subsequent agreement between the parties regarding the interpretation of the treaty or the application of its provisions." ${ }^{, 76}$ Therefore, the WTO treaty "explicitly frames itself in the wider context of public international law, including other non-WTO treaties."77

I agree with part of this opinion, as it is undisputable that the DSU may use other international agreements and bilateral treaties as a tool to clarify parties' obligations under the WTO agreement, such as Vienna Convention for example. However, neither Article 3(2) of the DSU nor Articles 31 and 32 of Vienna Convention provide that all relevant treaties between the disputing parties must be applied by the WTO's panel during the course of determining whether defendant has performed his obligation under the WTO covered agreement. ${ }^{78}$

Another argument is that WTO agreement is, in fact, a treaty, which means it is part of public international law, and the WTO agreement cannot be applied in a vacuum from other international law rules. In other words, Article 7 of the DSU does not need to set out all other rules of international law to be applied by the WTO's panels. ${ }^{79}$

The crux of this analysis is that based on the characterization of the WTO as an international agreement, there is no justification to isolate non-WTO rules on the ground that non-WTO agreements create international law obligations and these treaties serve as an applicable law, therefore, they cannot be ignored by the panel. ${ }^{80}$

The WTO agreement has no provision that imposes an obligation on the panel to examine the covered treaties between the disputing parties and assess their satisfaction of their obligation. The function of the DSU is to control the trade between the WTO members. Thus, the attempt to give RTA legal value to be applied by the WTO panel as part of the public international law is baseless. Further, WTO's

\footnotetext{
${ }^{74}$ Pauwelyn, supra (n 36), 1002-4.

${ }^{75}$ DSU, Article 3.2.

${ }^{76}$ Vienna convention on the law of treaties. Art. 31.3.(a).

${ }^{77}$ Pauwelyn, supra (n 36), 1001.

${ }^{78}$ Debra, supra (n 18), 8,9.

${ }^{79}$ Pauwelyn, supra (n 36), 1001.

${ }^{80} \mathrm{Id}$.
} 


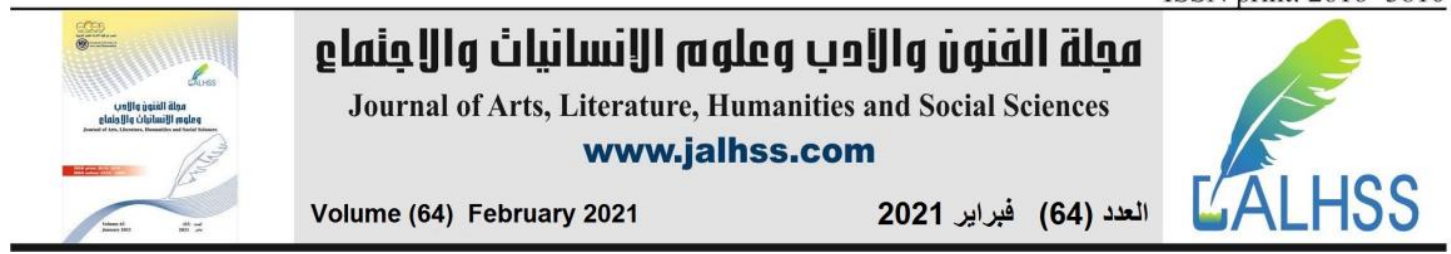

members did not grant a jurisdiction to DSB panel to hear any issue arising from other agreements. $^{81}$

\section{WTO Jurisdiction Prevails}

Article 23 of the DSU may prevail and preclude other jurisdictions from deciding the WTO law matters as Vienna Convention Article 30.2 states: "When a treaty specifies that it is subject to, or that it is not to be considered as incompatible with, an earlier or later treaty, the provisions of that other treaty prevail." ${ }^{82}$ Evidently, that forum selection in RTA cannot divest the jurisdiction of other tribunals established by other agreements: such bodies may still adjudicate claims arising under their agreements having provisions that operate in parallel to, or overlap with, the WTO provisions. Therefore, there is a need for WTO's members to address the issue of conflicting jurisdiction of both the WTO - RTA dispute settlement mechanisms.

Based on the Vienna Convention Article 30.2, it is possible that either the RTA or the WTO jurisdiction be seized, at the same time or in sequence, from adjudicating a very similar issue since the obligations under the RTA and the WTO are similar. In the absence of a treaty that addresses this issue, the principles of treaty interpretation appear to be the only reliable rules to resolve the issue of overlap or conflict of dispute settlement mechanisms. The issue is whether these conflicting rules are able to exclude the WTO dispute settlement mechanism or nullify its access, it is unlikely.

\section{Abuse of Process}

It may be argued that in public international law, a State, by bringing the same claim to a second tribunal, is abusing its process or procedural rights. A tribunal may decline to exercise jurisdiction if it believes that the motive behind this proceeding is to harass the defendant, or the allegations are frivolous or baseless. Realistically, it is rare that any judicial body, including DSU, would find the allegations frivolous. ${ }^{83}$

\section{SOLUTION}

It would be difficult to deny the WTO members' access to the DSU if the dispute is subject to RTA dispute settlement mechanism as Article 23 of the DSU imposes on members to resort only to DSU if they seek redress of a violation of the WTO obligations. The risk of having parallel proceedings does negate the fact that Article 23 of the DSU would prevail over RTA rules, and the WTO's panel would not hesitate to adjudicate any violation of the WTO's obligations submitted to it. The only solution, in my view, would be for WTO's members to negotiate an amendment to the DSU rules and incorporate a set of rules governing the allocation of jurisdiction

\footnotetext{
${ }^{81}$ Debra, supra (n 18), 5.

${ }^{82}$ Vienna Convention, Article 30.2

${ }^{83}$ Kyung Kwak and Gabrielle Marceau, Overlaps and Conflict of Jurisdiction Between The WTO and RTAS, conference on Regional Trade Agreements World Trade Organization, 26 April (2002), 7.
} 


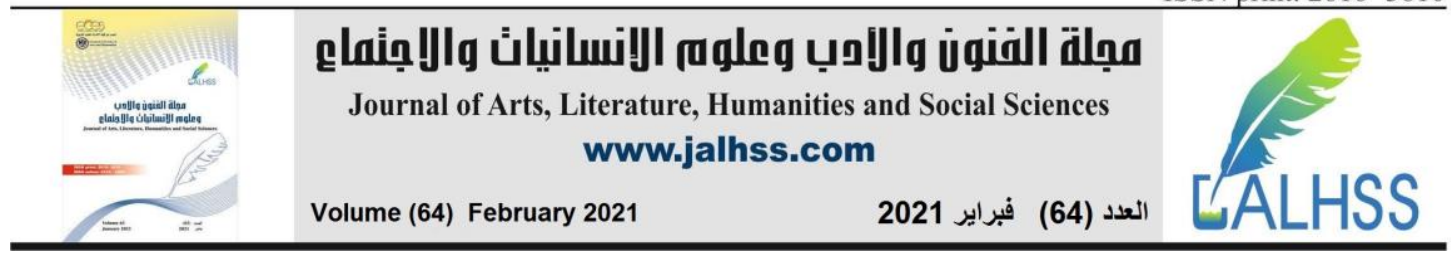

between the WTO and the RTA. The amendment of DSU rules should consider the recognition of the dispute settlement mechanism provision contained in the RTA, whether this provision is formulated to designate WTO as an additional forum or to exclude its capacity to decide the issue.

Suggesting that RTA members draft the forum clause in RTA consistently with DSU jurisdictional scope is unlikely to happen for two reasons; First, for this suggestion to be binding it has to be incorporated in DSU rules which would require an amendment to the DSU rules. Second, some countries intend to preclude the jurisdiction of the WTO when drafting their free trade agreement. In addition, all states have the right to bind themselves with any obligation and their freedom in this regard cannot be seized. In conclusion, this article has provided an analysis on the viability of the forum selection clause incorporated in the Regional Trade Agreement when: 1) all parties are WTO members, and 2) the dispute concerns the WTO obligations. Given the significant growth of RTAs, particularly when most of these agreements contain forum selection clause, it seems the conflict of jurisdiction between DSU and RTA dispute settlement mechanism is inevitable. This article, therefore, argues that this problem should be resolved in order for a consistent relationship between these two regimes. As discussed above, in light of the clear language of Article 23 of the DSU, all of the solutions suggested seem to be impractical. The negotiation between the WTO members is urgently needed in the absence of any international rules that might govern this issue. Also, there should be a set of interpretation rules to help avoid any potential conflict in the future between the RTAs and the WTO in terms of obligations or jurisdiction.

\section{References}

\section{Books}

1. Bin Cheng, General Principles of Law as Applied by International Courts and Tribunals, 1987

2. Peter R. Barnett, Res Judicata, Estoppel and Foreign Judgments, 2001

3. J.J. Fawcett, Decliding Jurisdiction in Private International Law , 1995

\section{Articles}

1. Candice Whyte, Yuval Shany, The Competing Jurisdictions of International Courts And Tribunals, 12 UNIVERSITY OF MIAMI INT'L AND COMPARATIVE L. REVIEW, 2004.

2. Pauwelyn. Joost, 'The Role Of Public International Law In The WTO: How Far Can We Go?' 95 (3) 95 J. INT’L L., 535.

3. Henry Gao and C. L. Lim, Saving the WTO From The Risk of Irrelevance: The WTO Dispute Settlement Mechanism As A 'Common Good' For RTA Disputes, J. INT'L ECON. L., 904.

4. Hillman, Jennifer, conflicts Between Dispute Settlement Mechanisms in Regional Trade Agreements and the WTO-What, Should the WTO Do, 42 CORNELL INT'L L.J. 


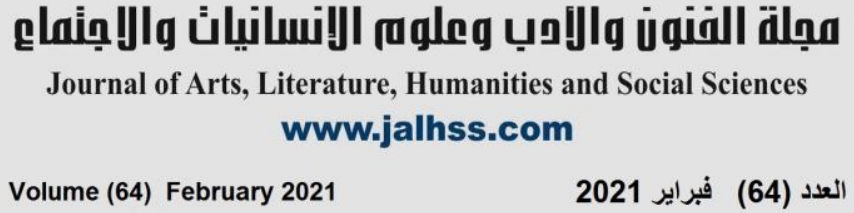

5. Kyung Kwak and Gabrielle Marcea, Overlaps and conflicts of Jurisdiction between the World Trade Organization and Regional Trade Agreements, The CanadianYearbook of Int'1 L.

6. Jennifer Lan, U.S. and Canadian Trade War over Softwood Lumber: The Continuing Dispute, 13 LAW \& BUS. REV.

7. Pauwelyn, Joost, How to Win a WTO Dispute Based on Non-Wto Law? Questions of Jurisdiction and Merits. Journal of World Trade.

8. Isabelle Van Damme, Treaty Interpretation by the WTO Appellate Body, 21 EUR. INT'L. L.

9. Nguyen Tan Son, Towards a Compatible Interaction between Dispute Settlement under the WTO and Regional Trade Agreements, 5 MACQUARIE J. Bus. L. 113 (2008).

10. Songling Yang, The Ssettlement of Jurisdictional Conflicts Between The WTO and RTAS: The Forum non Convenience Principle, 23 WJILDR.

Treaties

1. WTO Agreement: Marrakesh Agreement Establishing the World Trade Organization, Apr. 15, 1994, 1867 U.N.T.S. 154, 33 I.L.M. 1144 (1994).

2. North American Free Trade Agreement, U.S.-Can.-Mex., Dec. 17, 1992.

3. EFTA-Singapore Free Trade Agreement, 26 June 2002.

4. Protocolo de Olivos Para la Solucion de Controversias en el MERCOSUR, Feb. $18,2002$.

5. Vienna convention on the law of treaties.

6. Canada - US Free Trade Agreement, Jan. 2, 1988.

WTO-RELATED Documents

1. DSU, Dispute Settlement Rules: Understanding on Rules and Procedures Governing the Settlement of Disputes, Marrakesh Agreement Establishing the World Trade Organization, Annex 2, 1869 U.N.T.S. 401, 33 I.L.M. 1226 (1994)

2. WTO, Regional Trade Agreements-Facts and Figures: How Many Regional.

3. Argentina - Definitive Anti-Dumping Duties on Poultry from Brazil

4. Ireland v. United Kingdom

5. Panel Report, India- Measures Affecting the Automotive Sector, WT/DS146/R, WT/DS175/R (Dec. 21, 2001). Canada v. USA softwood lumber countervailing and anti-dumping measures

6. Appellate Body Report, United States-Final Dumping Determination on Softwood Lumber from Canada, at Art 21.5, 11 144-147, WT/ DS264/AB/RW (Aug. 15, 2006).

7. Panel Report, Argentina-Definitive Anti-Dumping Duties on Poultry from Brazil, WT/DS241/R, adopted on 19 May 2003 (not appealed), 7.38.

\section{Internet Sources:}

- WTO, Regional Trade Agreements-Facts and Figures: How Many Regional. Available at: https://www.wto.org/english/tratop_e/region_e/region_e.htm\#: :text=back\%20to\%2 0top,Facts\%20and\%20figures, the \%20GATT\%20or\%20the\%20WTO\%3F. 


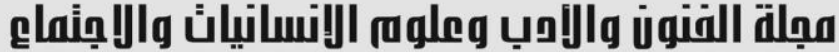

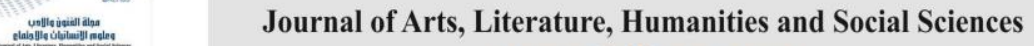 www.jalhss.com

\section{Working Paper, and Other Source}

- Steger, Debra P., Jurisdiction of the WTO (2004). Proceedings of the 98th Annual Meeting of the American Society of International Law, pp. 142-147, 2004, Available at SSRN: https://ssrn.com/abstract=2467273. 